\title{
The cultivation and physiological ecology of members of salt marsh epiphytic communities"
}

\author{
J. J. Lee, J. H. Tietjen, R. J. Stone, W. A. Muller, \\ J. Rullman and M. McEnery \\ Department of Biology, City College of City University of New York; \\ New York, USA
}

KURZFASSUNG: Die Kultivierung und physiologische Ökologie von Organismen epiphytischer Salzmarsch-Lebensgemeinschaften. Im Rahmen eines Programms zum Studium der Nahrungsbeziehungen und der Remineralisationsprozesse wurden Organismen der epiphytischen Lebensgemeinschaften von Zostera, Enteromorpha, Ulva und anderen Makrophyten isoliert und axenisch kultiviert. Das Ziel dieser Untersuchungen ist die Charakterisierung der mikrobiellen Lebensgemeinschaften aus nichtverschmutzten und durch Abwässer verunreinigten Meeresgebieten, die Erforschung der physiologischen OKkologie wichtiger Arten und ihrer Reaktionen unter verschiedenen Stressituationen sowie der Aufbau von Kleinstökosystemen, um die Regulationsmechanismen in derartigen epiphytischen Lebensgemeinschaften kennenzulernen. $Z u$ diesem $Z$ weck wurden unter axenischen Bedingungen Enteromorpha intestinalis, Ulva lactuca, ungefähr 70 Diatomeenarten, Chrysophyceen, Dinoflagellaten, Chlorophyceen, 6 Foraminiferen- und 3 Nematodenarten in Dauerkultur genommen; nicht keimfrei wurden auch zahlreiche Harpacticiden, Ostracoden, Amphipoden, Flagellaten und Ciliaten kultiviert.

\section{INTRODUCTION}

Recognizing the importance of marine resources, we are studying the physiological ecology of salt marsh epiphytic communities, particularly those in which foraminiferans and nematodes are the dominant herbivores.

It has been our hope that by means of laboratory and field studies we can gain enough information to develop a systems analysis approach to a model microcosm of a salt marsh epiphytic community.

Salt marsh epiphytic communities are almost ideal for studying the principles of ecological regulation. Their community structure is dynamic and complex. They are compact and isolated and yet communicate with the rest of the marsh by means of dissolved nutrients and relatively large herbivores and carnivores. Many of the organisms from the community have been, or can be, isolated and maintained in axenic culture and their physiological characteristics studied. The community is important in

* Supported by US Atomic Energy Commission contract AT (30-1) 3995 and NSF Grant GB 7796 (USAEC reference number NYO 3995-11). 
biogeochemical mineral cycling, and because it is representative of the shallow marine community which, by various estimates, is some 20,000 times greater in productivity than is the open sea.

Models of ecosystems now include some descriptive mathematical sets for the number of species and individuals of each species, the information content of each individual, physical conditions, energy input into the system, the information content of the energy input, the boundaries of the system, time lag phase shifts, the number and types of linkages between the components of the system, and the effects of time, environmental change, and other factors on community structure.

While data have been gathered for several models (MacArthur 1960, PATTEN 1962 , 1966) the amount of experimental information has restricted simulation to a small number of variables in comparison to the complexity of the actual coupled systems represented.

Some of the parameters of an ecosystem or model microcosm are easier to investigate than others. Thus there are much data available on physical and chemical resources, population structure and succession, primary productivity, community respiration, and net productivity. Very little is known about the fine details and channels of regulation and communication between components of the system. One cannot help but feel that the latter parameters might be most easily studied in microbial communities. In a small microcosm community interaction is conceptually a logical extension of cellular metabolism with its maze of overlapping and interlocking pathways leading to diverse end products. The impressive capacity of the living organism to regulate its metabolism and direct an orderly flow of precursor compounds along the multitude of biosynthetic pathways to provide adequate supplies of each critical end metabolite is due to endproduct regulation mechanisms.

We recognize, at present, two major mechanisms by which the end product of a biosynthetic pathway restrains those reactions which lead to its synthesis; namely, repression and feedback inhibition ("retroinhibition"). Repression refers to the situation in which accumulation of the end product leads to a cessation (repression) of the synthesis of various enzymes involved in its formation. In feedback inhibition the accumulation of the end product leads to a cessation (repression) of the synthesis of various enzymes involved in its formation. In feedback inhibition the accumulation of the end metabolite causes a specific inhibition of the activity of preformed enzymes catalyzing, usually, an early step in the pathway leading to the formation of the metabolite. While simple in principle, some of the mechanisms for end product regulation of divergent pathways (such as those leading from aspartate) are rather complex. The simple elegance of the isoenzymes of aspartokinase and other control mechanisms in the economy of the cell allows dynamic and selective restraints which are analogous to the regulatory mechanisms studied for years by ecologists (Lindeman 1942, LotKa 1956, VolTERRA 1931).

While our modeling goal may seem overly ambitious or even unattainable we have been making progress toward it during 8 years since we selected our collecting site in North Sea Harbor, Southampton, Long Island. The core of our program has been the attempt to isolate and culture axenically (or at least gnotobiotically) key members of the epiphytic community including higher and lower algae, fungi, bacteria, protozoa, 
and small metazoa. As new organisms are isolated their nutritional requirements and the effect of physical environmental variables, including stress, on their growth and reproduction is studied (LeE et al. 1963, Freudenthal et al. 1963, Lee \& Pierce 1963, Freudenthal \& Lee 1963, Lee et al. 1969 a, b, McEnery \& Lee 1969, Muller \& Lee 1969). By means of radionuclide labeled compounds and tagged organisms we have also made some initial studies of principle pathways in the food web (LEE et al. 1966). In related studies the exchanges of various soluble metabolites between selected members of the community and interspecific competition for food organisms and metabolites have also been investigated (Lee \& Pierce 1963, Muller \& Lee 1969).

\section{MATERIALS, METHODS AND RESULTS}

\section{Collection and initial isolation}

Selection of a field station or collecting site requires careful consideration. Our selection of Towd Point in North Sea Harbor, Southampton, New York was based on practical, as well as scientific reasoning.

With the gross limits set by such ecological factors as temperature, salinity, turbidity, $\mathrm{pH}$, depth and light, the organisms that we are interested in are not uniformly distributed in the environment. They may be found by the thousands in some spots and will be absent in collections taken only a few feet away. The subtle environmental factors responsible for this non-random distribution have thus far eluded detection by field methods. Although there is a report of significant numbers of foraminifera collected in the region of a sewer outfall (WATKINs 1961) in our region the once abundant organisms are no longer found in quantity within about 110 miles east of $\mathrm{New}$ York City. Their decline is perhaps correlated with urban and suburban growth and environmental pollution. The species-diversity principle which PATTEN (1962) used to show degrees of pollution in Raritan Bay (species diversity in the bay progressively increases with distance from the polluted Raritan River) seems generally true for the New York region. Collections of epiphytes in Plum Beach or Jamaica Bay, New York City, for instance have fewer species than those taken further west. Our field station in North Sea Harbor is relatively close to our laboratory ( $\sim 120$ miles), in a relatively unpolluted part of the Peconic Bay estuary system, and is relatively inaccessible from populous areas because of the swift channel at Towd Point. Over the past 10 years it has consistently had high standing crops of foraminifera.

Field stations in North Sea Harbor are visited biweekly at low tide during the summer months. By means of sterilized forceps, small samples $(0.2 \mathrm{~g}$ dry weight $)$ of Zostera, Zanichellia, Ulva, Enteromorpha, Polysiphonia, Ceramium, and occasionally Codium or Fucus are gently removed from the environment and inoculated into screwcap test tubes $(25 \mathrm{~mm} \times 150 \mathrm{~mm}$ ) containing $30 \mathrm{ml}$ of sterile sea water from the same environment. The "aseptic" samples are placed immediately in an insulated ice chest for transfer to our camper wagon refrigerator. Bulk collections of algae are sometimes gathered in plastic buckets to provide larger numbers of foraminifera and nematodes for experiments. The animals are harvested from the bulk collections in the field by 
"washing", in which a small handful of macroalgae or angiosperm is rubbed on itself. The epiphytic community is freed from the surface of the substrate and dispersed in the sea water. After washing a dozen or so handfuls, the contents of the pail are

Table 1

Base $\mathrm{S}$ initial isolation media

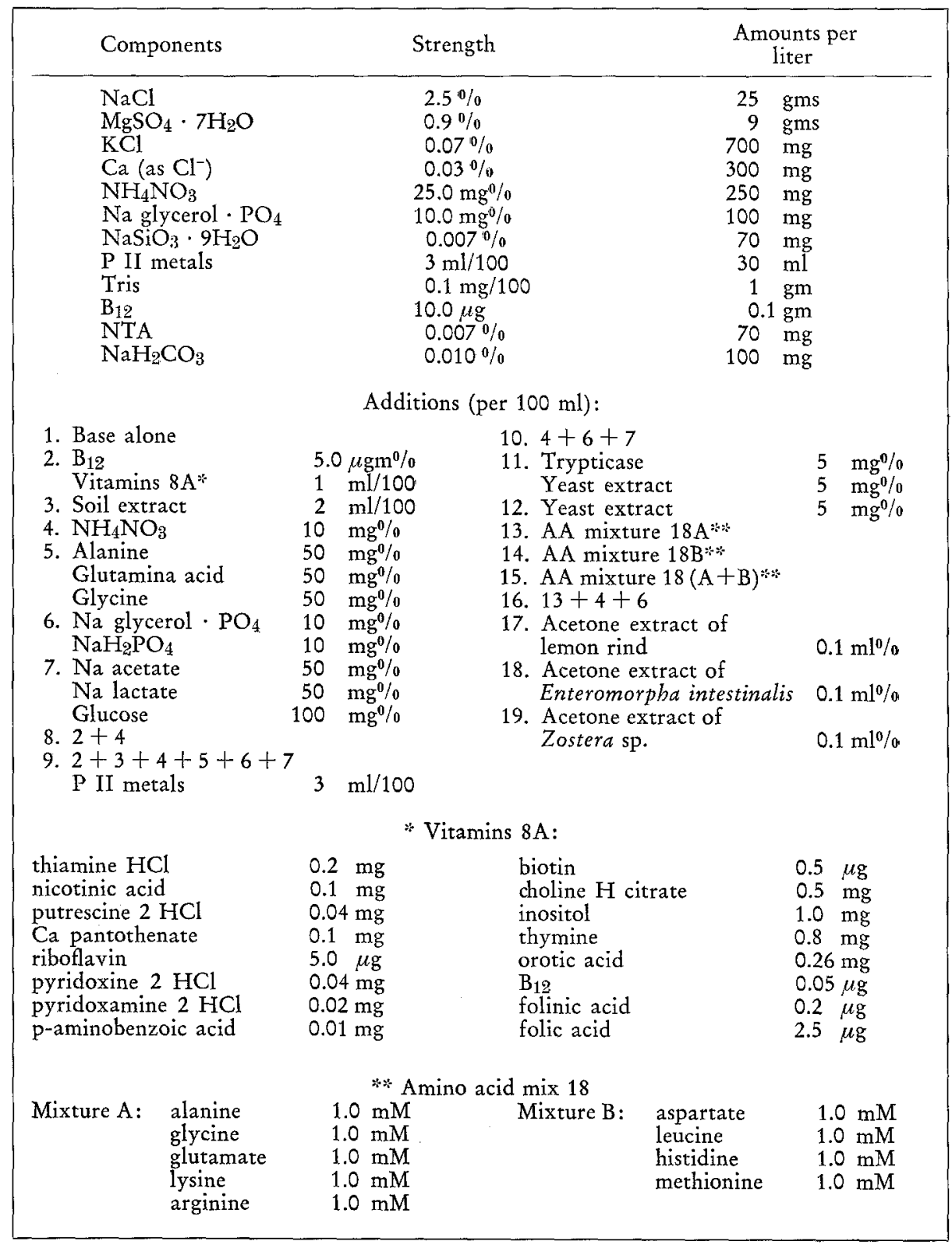


allowed to settle for approximately 10 minutes. The foraminifera and the sand grains fall almost immediately; the nematodes and epiphytic diatoms take longer. The pail is decanted and the sediment is poured through No. $4(4.76 \mathrm{~mm})$, No. $18(1.0 \mathrm{~mm})$, and No. $35(500 \mu \mathrm{m})$ sieves to remove the small clams, larger crustacea, annelids, and coarser sand grains. After a brief settling period $\sim 1.5 \mathrm{~cm}$ of sediment is placed in the bottom of $250 \mathrm{ml}$, wide-mouth, screw-capped plastic bottles. Approximately $200 \mathrm{ml}$ of fresh sea water is added to each bottle which is then also placed in the insulated ice chest.

As soon as possible the chilled aseptic samples are brought to a nearby field laboratory. By means of a stereoscopic dissecting microscope the samples are studied through the test tube walls. Those which contain "blooms" ( $>50$ animals/samples) are selected for further analysis (Fig. 1 a). The tubes are vigorously agitated with the aid of a vortex mixer to separate the epiphytes from their substrates. Small aliquots are inoculated into liquid differential media (Table 1), marine nutrient broth, Sabouraud's dextrose medium, erdschreiber, sea water, and streaked out on solidified agar plates of the same media. An estimate of the make up of the epiphytic community is also made by phase microscopy of an aliquot. Another aliquot is fixed in $70 \%$ alcohol and later Millipore filtered. This sample is studied to give an estimate of the diatom community structure. We have found that detailed microscopic examination of the samples is necessary to get an accurate picture of the epiphytic community as it existed at the time of collection. Many groups of organisms (i.e., flagellates, ciliates, fungi, etc.) are not visibly preserved on the Millipore filter. Other organisms, i.e., Dunaliella spp., Allogromia spp., Amphora spp., Nitzschia acicularis, etc. grow disproportionately well in the isolation media. The media are refrigerated and brought back to the laboratory where they are incubated in various incubators. Sets of media are incubated at either $15^{\circ} \mathrm{C}$, $20^{\circ} \mathrm{C}$, or $25^{\circ} \mathrm{C}$ in Sherer Model Cel 4-4 environmental chambers which are programmed for an $18 \mathrm{~h}$ light, $6 \mathrm{~h}$ dark cycle. We prefer this model environmental chamber because the movable shelves are illuminated from below. At various times we have incubated the petri plates in continuously illuminated incubators.

We estimate that by our present methods we can isolate $35-40 \%$ of the organisms in the community in continuous gnotobiotic culture. Our isolation media are based on those developed by Provasoli et al. (1957) and have been revised annually as we have gained more data on differential isolation and the nutritional and physiological optima for the growth of members of the community. The present set retains the most successful media from previous years (LeE et al. 1966). While our media have become progressively specialized for the isolation of members of the epiphytic community we are studying, we have on occasion used them for the isolation of organisms from similar environments. Media 12,13,14, 15, 22, and 26 (1966 series, LeE et al. 1966) made with a higher salinity base, were successfully employed to axenically isolate and later grow a symbiont from the foraminifer Archais angulatus collected from Thalassia testudinum beds in Biscayne Bay, Florida (LeE \& Zucker 1969).

The best medium for isolation of the greatest variety of epiphytic organisms is FøYNs' erdschreiber (Provasoli et al. 1967) which we prepare using sea water from North Sea Harbor and black unenriched potting soil from a commercial source in Southampton. Soil extract is prepared by autoclaving (15 Psi-30 min) equal amounts 
$(\mathrm{w} / \mathrm{v})$ of soil extract and water in covered enameled pots or stainless steel beakers. The bottoms of glass beakers have cracked with disastrous results for the autoclave. The autoclave pressure is allowed to drop very slowly to allow the steam which may be trapped in the soil to return to normal pressure. After the mixture is cool it is fil-

Table 2

Nutritional requirements of selected algal members of the epiphytic community

\begin{tabular}{|c|c|c|c|}
\hline $\begin{array}{l}\text { Strain } \\
\text { designation }\end{array}$ & Major stimulants & $\begin{array}{l}\text { Initial isolation } \\
\text { medium (LEE } \\
\text { et al. 1966) }\end{array}$ & Comments \\
\hline B1-1 & Soil extract & Erd, 4,15 & \multirow{2}{*}{$\begin{array}{l}\text { moderately } \\
\text { heterotrophic } \\
(\sim 15 \mathrm{mM}) \\
\text { very heterotrophic } \\
(\sim 25 \mathrm{mM})\end{array}$} \\
\hline SH-1 & $\begin{array}{l}\text { Vitamin mix S3 } \\
\text { Acetate } \\
\text { Lactate } \\
\text { Glucose }\end{array}$ & Erd, 9, 21 & \\
\hline RF 1 & $\begin{array}{l}\text { Aspartate } \\
\text { Histidine }\end{array}$ & Erd, 2 & \multirow{2}{*}{$\begin{array}{l}\text { inhibited by } \\
\text { concentration of high } \\
\text { organic substrates } \\
\text { moderately } \\
\text { heterotrophic }\end{array}$} \\
\hline RF 8 & $\begin{array}{l}\mathrm{NO}_{3}-+\mathrm{PO}_{4}= \\
\text { Acetate } \\
\text { Lactate } \\
\text { Glucose } \\
\text { Glutamate }\end{array}$ & 21,24 & \\
\hline 9 & $\begin{array}{l}\mathrm{PO}_{4}= \\
\text { Acetate, Lactate, Glucose } \\
\text { Glutamate } \\
\text { Phenylalanine } \\
\text { Arginine }\end{array}$ & $\begin{array}{l}\text { Erd, many } \\
\text { other media }\end{array}$ & very heterotrophic \\
\hline Bl-15A & $\begin{array}{l}\text { Alanine } \\
\text { Glycine } \\
\text { Glutamate }\end{array}$ & 4 & $\begin{array}{l}\text { inhibited by } \\
\text { high concentration of } \\
\text { organic substrates }\end{array}$ \\
\hline Bl-17 & $\begin{array}{l}\text { Acetate } \\
\text { Lactate } \\
\text { Glucose }\end{array}$ & 21 & very heterotrophic \\
\hline 38 & $\left.\begin{array}{l}\text { Acetate } \\
\text { Lactate } \\
\text { Glucose }\end{array}\right\}+$ Vitamin mix & Erd & very heterotrophic \\
\hline 39 & $\left.\begin{array}{l}\text { Acetate } \\
\text { Lactate } \\
\text { Glucose }\end{array}\right\}+$ Vitamin mix & Erd & very heterotrophic \\
\hline 50 & $\begin{array}{l}\mathrm{NO}_{3}- \\
\text { Galactose } \\
\text { Cystine } \\
\text { Arginine } \\
\text { Lysine } \\
\text { Histidine }\end{array}$ & 6,16 & $\begin{array}{l}\text { inhibited by } \\
\text { high concentration of } \\
\text { organic substrates }\end{array}$ \\
\hline 55 & Yeast extract & 13 & $\begin{array}{l}\text { moderately } \\
\text { heterotrophic }\end{array}$ \\
\hline
\end{tabular}


tered through cheese cloth and \# 1 Whatman filter paper. The filtrate is then frozen, thawed, and refiltered through \# 1 Whatman filter paper. Sometimes it is necessary to repeat the freezing process. Finally the extract is filtered through a Millipore HA $(0.45 \mu \mathrm{m})$ filter. The clear brownish extract is then diluted to a straw-yellow color with water and stored in a freezer. Stock solutions are protected with volatile preservative (HUTNER et al. 1958) and stored in the refrigerator.

Other media including sea water and the differential series support much less varied communities than erdschreiber. Although we have had 5 years of experience with various series of differential media, it is difficult to generalize about initial separations. Some organisms in the inoculum grow initially in a restricted group of media (i.e., Enteromorpha intestinalis and Ulva lactuca grew in media 4, 7, and erdschreiber; Rhabditis marina grew in media $2,7,9,10$; other organisms grow in a variety of media.

Nutritional studies on some of the algal isolates have shown that there is quite a range of heterotrophic requirements among members of the epiphytic community (Table 2). In some instances the initial isolation medium (a) directly reflected the nutritional requirements of the isolates; in others it did not. The selectivity of the media thus reflects in part the nutritional requirements of the organism; possible inhibition by medium components; and its competitive situation with respect to other organisms in the inoculum. Antibiosis occasionally observed around diatom clones (Fig. 3) suggests that this mechanism is also an operational factor in isolation from natural sources.

Table 3

Antibiotic mixes (all values in $\mu \mathrm{g} / 100 \mathrm{ml}$ )

\begin{tabular}{|c|c|c|c|c|c|c|}
\hline Components* & $\operatorname{Mix} 2$ & Mix 3 & $\operatorname{Mix} 4$ & Mix 5 & $\operatorname{Mix} 7$ & Mix 8 \\
\hline Chloromycetin & 250 & 250 & & 250 & & \\
\hline & 200 & & & 400 & & \\
\hline Coly-mycin & & & & & & \\
\hline Erythrocin & & & 50 & & 100 & 100 \\
\hline Dihydrostreptomycin $\mathrm{SO}_{4}$ & & 2,000 & & & & \\
\hline Fungizone & & & 50 & & & 50 \\
\hline Myco & & & & 50 & & \\
\hline Aerosporin & & 60 & & & & \\
\hline \multicolumn{7}{|c|}{ * Aerosporin (Polymyxin B Sulfate), Burroughs Wellcome \& Co. Tuckahoe, N.Y. } \\
\hline \multicolumn{7}{|c|}{$\begin{array}{l}\text { Albamycin (Novobiocin sodium), Mix-0-vial; n, n,-Dimethylacetamide (Diluent) } 10 \% \\
\text { v/v. The Upjohn Co., Kalamazoo, Michigan. }\end{array}$} \\
\hline \multicolumn{7}{|c|}{$\begin{array}{l}\text { Chloromycetin (Chloramphenical-[Sodium succinate]), Parke, Davis \& Co., Detroit, } \\
\text { Michigan. }\end{array}$} \\
\hline \multicolumn{7}{|c|}{$\begin{array}{l}\text { Coly-mycin (Sodium colistimethate), Warner-Chilcott Laboratories Div., Morris Plains, } \\
\text { New Jersey. }\end{array}$} \\
\hline \multicolumn{7}{|c|}{ Erythrocin (Erythromycin lactobionate), Abbott Laboratories, North Chicago, Illinois. } \\
\hline \multicolumn{7}{|c|}{ Fungizone (Amphotericin B), E. R. Squibb \& Sons, Inc., New York, New York. } \\
\hline & & & & & & \\
\hline
\end{tabular}




\section{Axenic or gnotobiotic isolation}

Only rarely has it been possible to isolate an axenic algal clone from solidified initial isolations. In practice we restreak clones on the same media and make streaks from the initial liquid isolation media. All picking and re-isolation operations are performed under a stereoscopic microscope contained within a microscope glove box (GermFree), Motile organisms are isolated from liquid media by aseptic washing. The inoculum is transferred into the 1 st well of a Pyrex 9-hole spot plate contained within a $150 \times 20$ petri dish. By means of a fine capillary pipette drawn from a Pasteur pipette, individual organisms with a minimum of medium are transferred to the next well filled. with sterile media. Sometimes the transfer media contain antibiotics (Table 3). The organisms are allowed to swim for about $5 \mathrm{~min}$ through the media in each of the first 27 wells. They remain in the 28 th well from $2 \mathrm{~h}$ to several days and their viability is noted through the cover of the petri dish. After an appropriate interval the organisms in the last well are transferred to test tube culture. The efficacy of the washing regime for each organism can only be determined empirically. On the first attempt to isolate a particular organism, aseptic samples of representative wash baths are inoculated into sterility test media. Axenic stock cultures are usually maintained on medium $S$ (Table 4).

Table 4

Stock maintenance medium $\mathrm{S}$

\begin{tabular}{|c|c|c|c|}
\hline Components & $g / 1$ & Components & $\mathrm{g} / \mathrm{l}$ \\
\hline 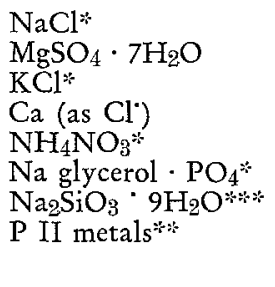 & $\begin{array}{l}25.0 \\
9.0 \\
0.7 \\
0.3 \\
0.25 \\
0.1 \\
0.07 \\
30.0 \mathrm{ml} / 1\end{array}$ & $\begin{array}{l}\text { tris* } \\
\text { vitamin } \mathrm{B}_{12} * \\
\mathrm{NTA}^{*} \\
\mathrm{NaH}_{2} \mathrm{CO}_{3}^{*} \\
\text { aspartic acid* } \\
\text { glycine* } \\
\text { glutamic acid* } \\
\text { alanine** } \\
\text { glucose* }\end{array}$ & $\begin{array}{l}1.0 \\
10 . \mu \mathrm{g} \\
0.007 \\
0.1 \\
0.66(=0.5 \mathrm{mM}) \\
0.037(=0.5 \mathrm{mM}) \\
0.073(=0.5 \mathrm{mM}) \\
0.044(=0.5 \mathrm{mM}) \\
0.090(=1.0 \mathrm{mM})\end{array}$ \\
\hline \multicolumn{4}{|c|}{$\begin{array}{l}\text { * Dry mix components; mixed in } 1001 \text { batches, then mixed in a porcelain mill, pre- } \\
\text { weighed in } 5 \mathrm{l} \text { amounts in freezer bags, and stored in a freezer. }\end{array}$} \\
\hline \multicolumn{4}{|c|}{$\begin{array}{l}* * \text { Sodium-meta-silicate should be added first and be allowed to dissolve completely be- } \\
\text { fore anything else is added. Each addition should be dissolved completely before the } \\
\text { next addition. The medium should be continuously stirred while the additions are } \\
\text { being made. }\end{array}$} \\
\hline
\end{tabular}

\section{Isolation and culture of Enteromorpha intestinalis}

The isolation of Enteromorpha intestinalis in axenic culture presented unusual problems. Organisms collected in the field were refrigerated and brought back to the city laboratory, where they were serially washed through 20 tubes of $30 \mathrm{ml}$ of sterile sea water in $25 \times 100 \mathrm{ml} \mathrm{screw-cap}$ test tubes and inoculated into the differential 
isolation media (Table 1). Thorough agitation was accomplished with the aid of a vortex mixer. After 30 days incubation, growth was observed only in media 4 and 8 . Some tubes were diatom free. The best strands were withdrawn from the tubes aseptically by catching and winding them onto a sterile, hookshaped inoculating needle. They were transferred to sterile sea water, washed aseptically through 20 serial washes, and layered out on the surface of sterile marine nutrient agar plates. Working under a dissecting microscope in a Germ-Free microscope glove box, the needles of sterile plastic syringes $(1 \mathrm{ml})$ were used as scalpels to hold and dissect open sections of $E$. intestinalis thalli. A sterile inoculating needle was then used to drag the sections through the agar. A total of 79 separate sections were thus isolated and inoculated into separate tubes of basal medium. After 7 days incubation, a sterility test was made from each of the isolates.

Many of the inocula failed to grow. Some of the isolates were bacteria free, but all were contaminated with a white fungal mycelium. After three weeks and apparently after zoospore formation, the walls of many isolates were covered with young feathery (multibranched) thalli (Fig. 1c). Inocula from these tubes were transferred to medium 8 or sea water with the same supplements (vitamin mix $8 \mathrm{~S} 1 \mathrm{ml} / 100$, vitamin $\mathrm{B}_{12} 0.000005 \%, \mathrm{NaNO}_{3} 0.01 \%$, and $\mathrm{NH}_{4} \mathrm{Cl} 0.01 \%$ ) plus a graded series of fungicides. Actinodione was tested within a range of $0.0001-1 \%$. Mycostatin and Gresiofulvin were tested within a $0.001-1 \%$ range.

After incubation for 20 days, all tubes contained fungi. At concentrations above $0.01 \%$, Actinodione and Gresiofulvin killed the algae. Enteromorpha intestinalis was greenest in the tubes with low concentrations of Mycostatin, where there were also extensive clumps of filamentous growth. When the tubes were examined through the walls at $100 \times$ magnification under a compound microscope, fungal mycelia could be seen among the algal filaments.

Inocula from the best tubes were transferred into medium 8 with Amphotericin B (Squibb intravenous with sodium desoxycholate and phosphate buffer) in the range of $0.001-0.2 \%$. After 7 days there was a small amount of algal filament outgrowth and no mold growth in the lowest concentration of Amphotericin tested. At the $0.01 \%$ level, algal growth was also inhibited, although the filaments were still green. At $0.02 \%$ Amphotericin the algae were undergoing apochlorosis. Algal filaments from the best tubes were transferred into 6 tubes of medium 8 with $0.001 \%$ Amphotericin B, and 6 tubes with no antibiotic.

Three days later fungal growth was obvious in transfers to media without antibiotics. Three tubes received fresh antibiotics and three did not. For the next 30 days the media were changed every 3 or 4 days and fresh antibiotics in the range of 0.001 $0.01 \%$ were added. After 30 days algal growth was inhibited in all concentrations of the antibiotic. Some fungal growth was noticeable in tubes with $0.001 \%$ Amphoteri$\operatorname{cin} \mathrm{B}$.

Individual filaments of differentiated Enteromorpha intestinalis growing in $\mathrm{My}$ costatin-inhibited cultures were transferred to the surface of nutrient agar plates. Algal filaments were dragged through the agar with a sterile inoculating loop, and dissected as before with sterile syringe needles. They were scraped with the needles to remove adhering fungal filaments and inoculated into a variety of media at $\mathrm{pH} 8$ and 9 , 

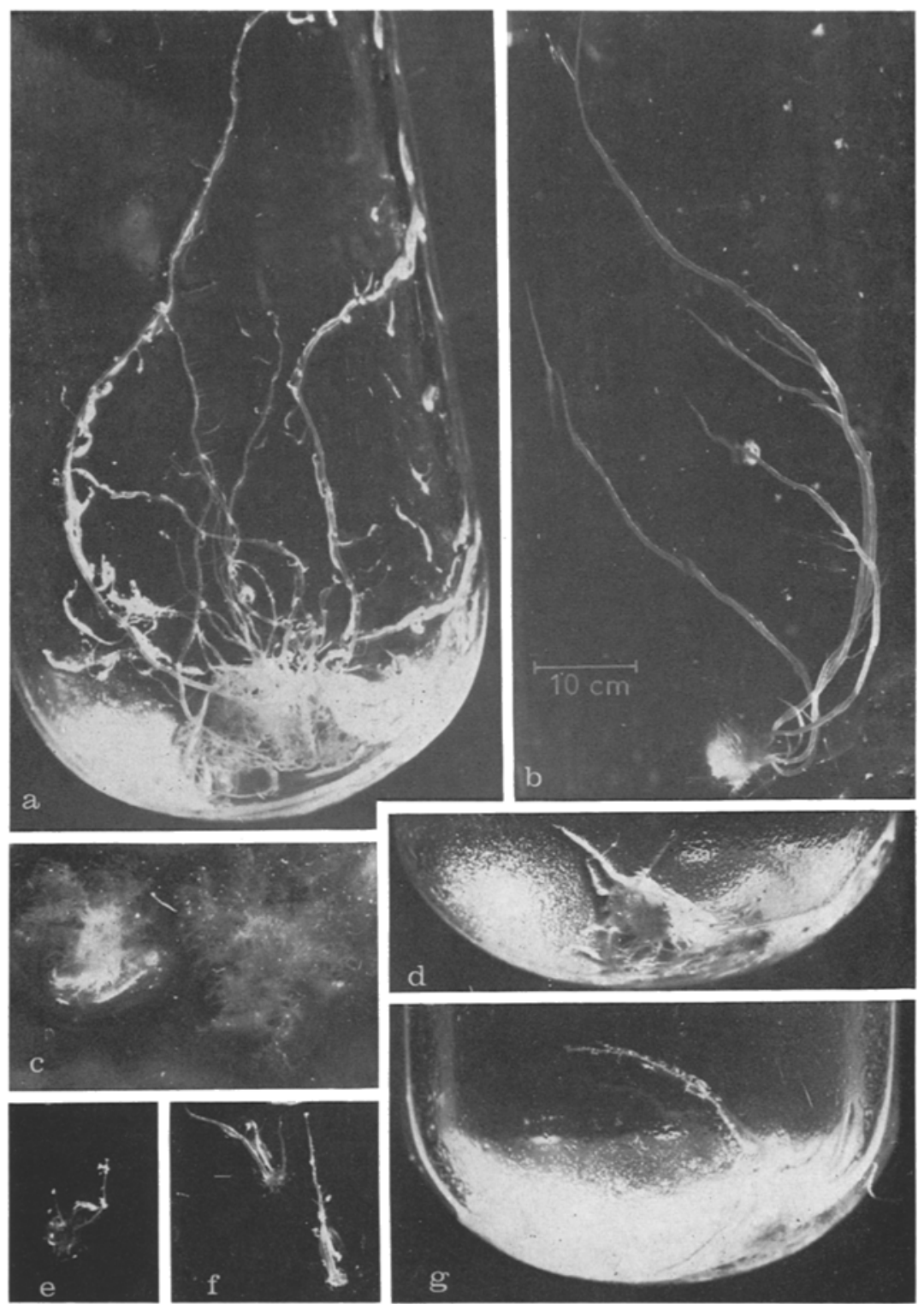

Fig. 1: Enteromorpha intestinalis. Photographed macroscopically with a $35 \mathrm{~mm}$ reflex camera through the test tube walls. All figures photographed at the same magnification and enlarged to approximately the same degree. Test tubes were $20 \times 125 \mathrm{~mm}$ screw-cap borosilicate tubes and are magnified slightly less than 5 times. a: Growth after 16 days of strain 60 (monoxenic) in medium 8 supplemented with incomplete supplement \# $301 \mathrm{ml} / 100(\mathrm{v} / \mathrm{v})$. $b$ : Growth after 16 days of strain 9 (axenic) in medium 8 supplemented with fresh frozen Enteromorpha intestinalis extract $1 \mathrm{ml} / 100 . c$ : Feathery growth in unsupplemented medium 8. $d$ and $g$ : Linear outgrowth of thalli through Mycostatin precipitate during antibiotic treatment. $e$ and $f$ : Typical linear growth of thalli under a variety of nutritional supplements (see Table 5) 
including sea water, erdschreiber, medium 8 , and variants of medium 8 . Tubes of each medium contained no antibiotic, Amphotericin B $0.05 \%$ or Mycostatin $0.05 \%$, or both. Sterility controls for the filaments after dragging them through the last agar indicated the effectiveness of the method. Only one mold colony grew in the initial sterility check of the 40 isolates. The first plates through which the individual algal filaments were dragged contained about 100 fungal colonies per plate.

After 7 days incubation the tubes with sw +8 and $50 \mu \mathrm{g} / \mathrm{ml}$ Mycostatin contained the healthiest Enteromorpha intestinalis and no fungal growth. Sterility checks of the 40 tubes in the experiment indicated that 7 contained mold although no mold filaments were yet visible.

Feathery clumps of Enteromorpha intestinalis from the best looking tubes were transferred to 40 tubes of medium sw +8 with Mycostatin $0.05 \%$ and into 10 tubes without antibiotic. After 7 days no fungal filaments were observed. Enteromorpha intestinalis were observed just above the Mycostatin precipitate at the bottom of the tubes (Fig. 1d, g). Extensive fungal growth was observed in controls transferred into media without antibiotics.

Ten of the 40 tubes from the previous experiment were transferred to fresh medium with no Mycostatin. Ten were transferred to fresh medium with Mycostatin $0.05 \%$. Half the medium was withdrawn from the remaining 20 tubes and replaced with fresh medium. To 10 of the tubes with replaced medium, $10 \mu \mathrm{g}$ Mycostatin was added per $10 \mathrm{ml}$.

After 7 days, sterility of the isolates was checked. Seventeen were axenic, 33 were bacterized with 1 or more types of bacteria; 3 of those without Mycostatin also contained fungus.

None of the axenic cultures grew after 2 months incubation. Feathery growth was observed in the bacterized cultures.

Sensitivity of the bacteria in the various isolates was checked by means of BBL sensidiscs. For various isolates Erythromycin $0.05 \%$, novobiocin $0.01 \%$ and chloramphenicol $0.02 \%$ seemed effective, but the algae eventually died.

Ten monoxenic stocks were inoculated into a variety of enriched Coney Island sea water media and synthetic enriched media. After 14 days, growth was obtained only in the synthetic media. During the next 30 days the algae in the sea water media gradually became pale green. Half the tubes were transferred to fresh sw +8 enrichments, the other half to medium 8 . In another 30 days the algae transferred to the sw media were dead; some of the algae transferred to the synthetic medium had regreened and grown.

Feathery clumps of the fastest growing 4 strains $(9,10,44,60)$ were inoculated into a nutritional enrichment experiment with medium 8 as base, and novobiocin $0.001 \%$ plus chloramphenicol $0.002 \%$. Linear outgrowth was noted in one strain (9). Monoxenic stocks of 3 strains $(10,44,60)$ were inoculated into an additional nutritional experiment (Table 5). Some linear outgrowth was noted in the unsupplemented controls (Fig. 1e). In the axenic strain (9) linear outgrowth was improved in the presence of a combination of thymine $0.1 \mathrm{mM}$, uracil $0.1 \mathrm{mM}$, and cytosine $0.1 \mathrm{mM}$ (Fig. 1f), and was 10 times greater with the addition of a fresh frozen and filtered Enteromorpha intestinalis aqueous extract (Fig. 1b). The latter was autoclaved after 
Table 5

Stimulation of linear growth of Enteromorpha intestinalis (Medium 8, linear growth of the longest filament, in $\mathrm{mm}$, after 28 days incubation)

\begin{tabular}{|lrrrr|}
\hline \multicolumn{1}{|c}{ Stimulants } & \multicolumn{3}{c|}{ Strain } \\
\hline Unsupplemented basal medium & 9 & 10 & 44 & 60 \\
\hline 2. NaH $\mathrm{PO}_{4} 0.1 \mathrm{mM}$ & 3 & 11 & 5 & 10 \\
Na glycerol phosphate $0.1 \mathrm{mM}$ & 4 & 15 & 8 & 15 \\
3. Adenine $0.1 \mathrm{mM}$ & 3 & 12 & 4 & 30 \\
Guanine $0.1 \mathrm{mM}$ & & & & \\
4. Thymine $0.1 \mathrm{mM}$ & 5 & 22 & 11 & 25 \\
Uracil $0.1 \mathrm{mM}$ & 0 & 0 & 0 & 0 \\
Cytosine $0.1 \mathrm{mM}$ & 3 & 0 & 8 & 35 \\
5. Complete supplement \# $13 \quad 1 \mathrm{ml} / 100$ & 0 & 0 & 0 & 0 \\
6. Incomplete supplement \# $30 \quad 1 \mathrm{ml} / 100$ & 0 & 0 & 0 & 0 \\
7. Indole-3 acetic acid $0.01 \mathrm{mM}$ & 35 & 3 & 20 & 15 \\
8. Gibberellic acid $0.01 \mathrm{mM}$ & & & & \\
9. Entestinalis extract $1.0 \mathrm{~m} / 1000$ & & & \\
\hline
\end{tabular}

addition to the basal medium. The diameter of the filaments in this tube was greater than in any tube in the experiment. A similar but less dramatic response to $E$. intestinalis-extract was noted in strains 44 and 60 . No response to this extract was apparent in strain 10. All the strains responded to equimolar $(0.1 \mathrm{mM})$ mixture of thymine, uracil and cytosine. Strain 60 was stimulated by an equimolar $(0.1 \mathrm{mM})$ mixture of adenine and guanine, and Haskins incomplete supplement mixture 30 (Fig. 1b). The latter tube had the greatest branching of all the tubes with extensive linear outgrowth. Additional experiments are incubating.

\section{Isolation and culture of Ulva lactuca}

Ulva lactuca was much more easily isolated in monoxenic culture than Enteromorpha intestinalis. A very healthy but detached thallus of Ulva lactuca was collected at our field station 17 (LEE et al. 1969b). It was placed in a "whorl-pack" and refrigerated until it was brought back to the city laboratory. On the following day the thallus was torn into small strips which were inoculated into sterile sea water in $20 \times$ $125 \mathrm{~mm}$ screw-cap test tubes. The tubes containing the strips were vigorously vibrated in a vortex mixer. By means of an inoculating needle bent into hook shape, the strips were aseptically removed from the test tubes and transferred into fresh media. The strips were serially washed 10 times before inoculation into tubes of the differential series of media (Table 1). The tubes were incubated in high light $(\sim 85 \mathrm{~cd} / \mathrm{sr})$. After 3 weeks incubation, survival of cells in the strips was observed in a variety of media, particularly those which were not heavily bacterized. Color of the strips was the criterion for survival; apple green was judged positive and pale yellow judged negative. In many strips, some macroscopically visible reorganization of the cells seemed to have taken place. Examination of the changes was by microscopic observation through the 

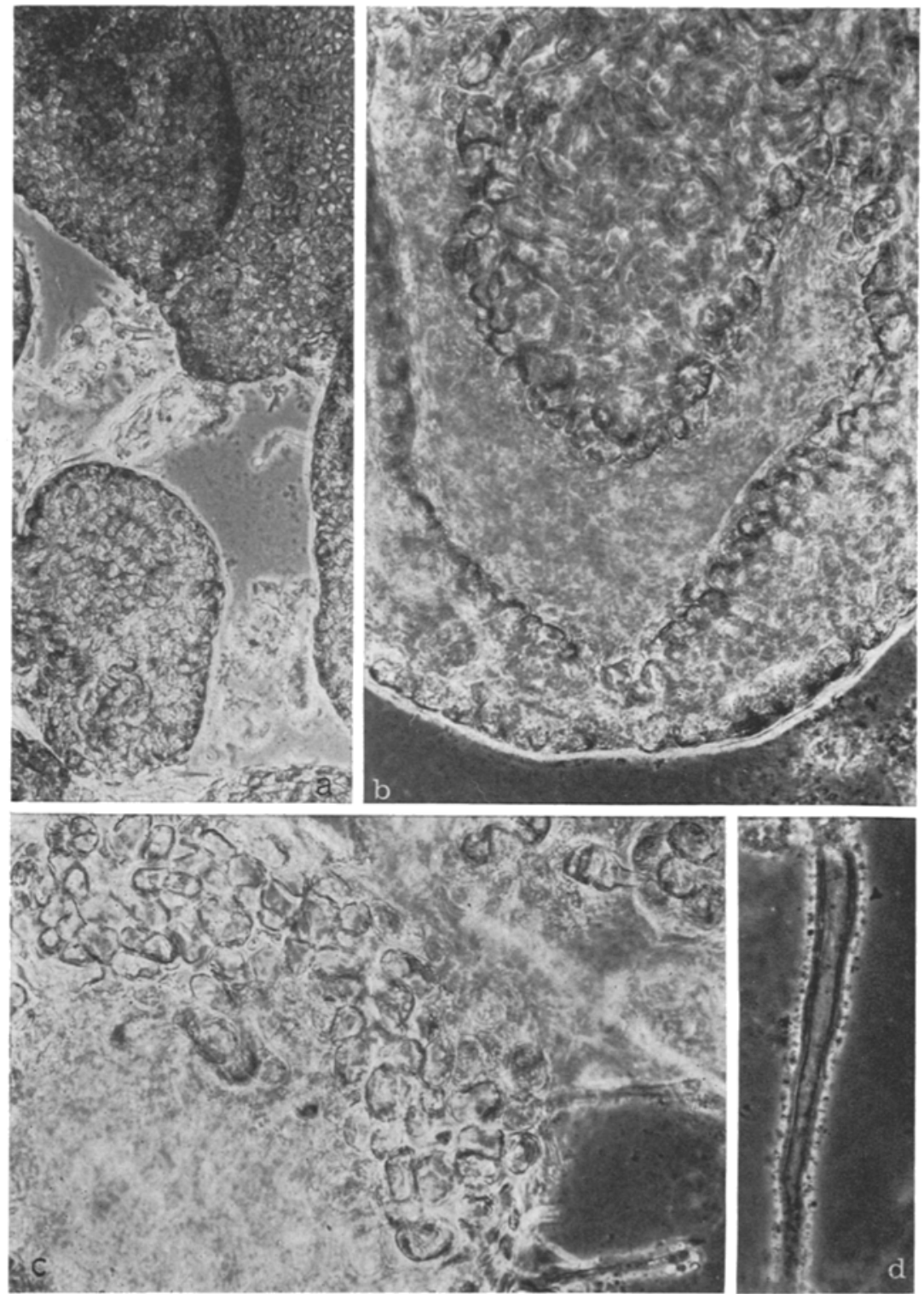

Fig. 2: Ulva lactuca. Viewed by phase microscopy, in monoxenic culture in supplemented erdschreiber enriched sea water media. Photographs taken at initial magnification of 32-128 $\times$; appear in figure at indicated magnifications. a: General view of thalli and holdfasts. Greatest thalli diameter roughly $2-5 \mathrm{~mm}$. $b$ : Young thallus undergoing final closure $(\sim \times 400), c:$ Basal region showing holdfasts; chromatophores and stigma seen in some cells $(\sim \times 500)$. $d$ : Holdfast showing full differentiation $(\sim \times 600)$ 
test tube walls. The study was never completed because in many tubes small $2-3$ cell green colonies were observed on the test tube walls. Because of the possibility that either zygotes or zoospores might be responsible for the colonies, the positive tubes were agitated vigorously. Small samples $(0.2 \mathrm{ml})$ were pipetted onto the surface of agar, solidified erdschreiber, sea water, $\mathrm{Q}$, and isolation media.

After incubation, bacterial colonies were observed in most media. Between the bacterial colonies on some plates, small green colonies were observed after a week.

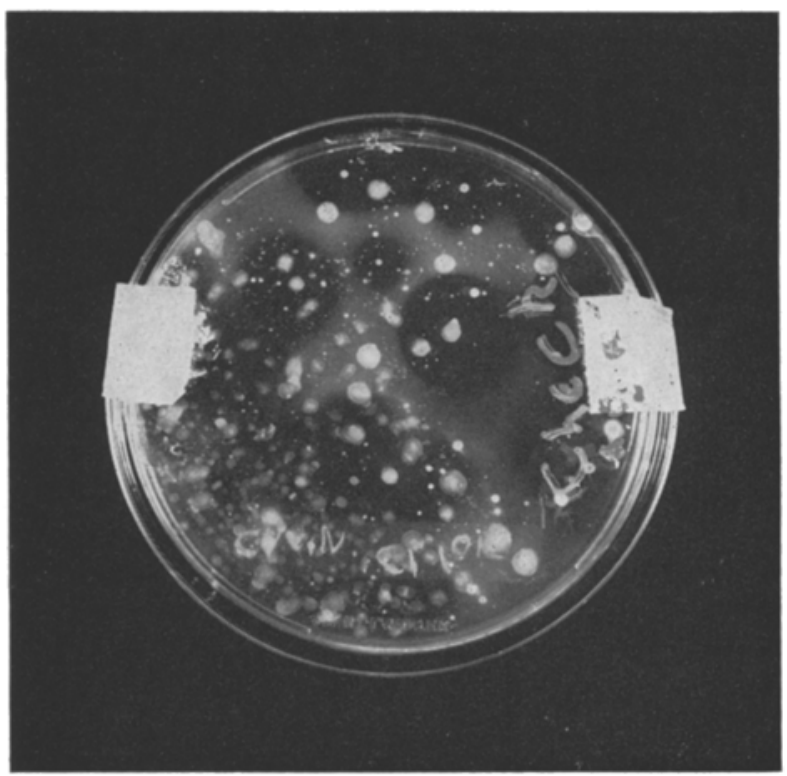

Fig. 3: Diatom growth inhibition by bacterial colonies on selective isolation agar plate streaked with a raw sample from the field

Under the dissecting microscope in the microscope glove-box, these colonies were picked with a fine (\# 26) inoculating needle and transferred to fresh media of the type in which they were already growing. The original plates and the transfers were incubated in strong light $(\sim 85 \mathrm{~cd} / \mathrm{sr})$ for 2 weeks. Except for bacterial growth, no growth was observed on the transfers. On several original sea water and erdschreiber plates very small thalli were observed. Those thalli growing in areas free of bacterial colonies were transferred in the microscope glove-box to liquid and solidified erdschreiber, sea-water, S, and differential media 1, 4, 6, and 8 . The transfers were incubated for 2 weeks at various light intensities in the environmental chamber. Sterility tests indicated the presence of a single bacterial type. It is a rather slow growing species.

Many transfers were successful and small thalli were observed in erdschreiber, sea water, and S. Of all the variables tested, best growth was obtained on solidified erdschreiber grown at the highest light intensity tested. Some of the larger thalli were transferred to fresh plates, liquid media, and solidified media in tubes ("slopes") 
overlayed with liquid media. After incubation for 1 month, the erdschreiber slopes overlayed with liquid media showed best growth with fully differentiated thalli (Fig. 2a-d) averaging $0.5-1 \mathrm{~cm}$ in diameter. Several thalli have reached $3 \mathrm{~cm}$ in length. The thalli seem to reach larger sizes if the medium is changed biweekly. Several thousand thalli are now in monoxenic culture and experiments to obtain axenic culture will begin shortly.

\section{Culture of Foraminifera}

Angotobiotic cultures of Foraminifera are easy to establish in environmental chambers or in a laboratory in which the room temperature seldom exceeds $20^{\circ} \mathrm{C}$. In the laboratory the contents of plastic collecting bottles are again agitated. After a brief settling period the supernatant fluid is decanted and the sediment is washed out with Millipored sea water into Pyrex baking dishes $(34 \times 23 \times 5 \mathrm{~cm})$ until $2-5 \mathrm{~cm}$ of sea water overlay the sediment $(\sim 0.5 \mathrm{~cm}$ thick). The dishes are stacked and left undisturbed for about $12 \mathrm{~h}$, during which time the foraminiferans crawl up through the sediment to the surface. If the collection has been good they can be seen with the unaided eye as small white, orange, or pink dots in balls of surface algae. During the next 2 or 3 days the balls of algae and foraminiferans are gently harvested by suction from the surface by means of a Pasteur pipette with rubber pipetting device (Propipette). The foraminifera and algae are placed in a test tube of Millipore filtered sea water from the collecting area and agitated for $\sim 5$ min with the aid of a vortex mixer. After the foraminifera are allowed to settle out to the bottom the lighter sediment is decanted. This procedure is repeated about 5 times. The sediment with the foraminifera is then examined in a fingerbowl or petri dish under a stereomicroscope. The foraminiferans are then picked from among the sand grains, ostracods, and similar density invertebrates and particles with glass needles and Pasteur pipettes. Approximately 100 carefully washed foraminifera are inoculated into $50 \mathrm{ml}$ sea water from the collecting site, or erdschreiber, plus the appropriate food organisms. We prefer to use finger bowls which stack tightly as culture vessels for agnotobiotic culture. Evaporation is further retarded by broad rubber bands (Petri dish seals; Fisher Scientific Co.) which are placed around the junction of the stacked finger bowls. Foraminifera are selective feeders. Quite a number of different algae have been used as food for foraminifera (see review Mulder \& LeE 1969). Of all those tested, Nitzschia acicularis, Cylindrotbeca closterium, Phaeodactylum tricornutum, Amphora spp., Nitzschia brevirostris, Dunaliella parva, D. salina, Chlorococcum sp. and Nannocbloris sp. seem to be the most useful. We have found that tracer feeding experiments greatly shorten the time required to screen potential food organisms to be used to establish gnotobiotic cultures (LeE et al. 1966). Briefly, axenic potential food organisms are grown in ${ }^{32} \mathrm{P}$ labeled media, the specific activity of which is adjusted so that the algae will be labeled $\sim 0.5-5 \mathrm{dpm} /$ organism at the time of harvest. The labeled food is washed free of unincorporated label, harvested by centrifugation, and fed to the foraminifera. After a brief incubation (1-2 days) the foraminiferans are harvested from the cultures, and with the aid of glass needles, separated from uneaten algae. Three factors effect feeding: the age of the food organism, the stage in the life cycle of the foraminifera, 
and the concentration of the food. Foraminiferal consumption of most food is erratic below a concentration of $10^{3}$ food organisms, and is about directly proportional to concentration within a range of $10^{3}-10^{6}$ food organisms near the food web of the test foraminiferans. Small A. laticollaris $(\sim 150-200 \mu \mathrm{m}$ in diameter) ate many more food organisms than did larger $(350-400 \mu \mathrm{m}$ specimens. The feeding behavior of Ammonia beccarii was effected by the physiological age of the food organism, while the same factor did not effect Allogromia laticollaris. Foraminifera grow better if the algae is grown separately from the food, washed free of waste products by centrifugation, and fed to the foraminifera (MULLER \& LEE 1969). The foraminifera thus far studied have complex nutritional requirements. These are best satisfied by a combination of food organisms rather than a single one (LEE \& McENERY 1969, Muller \& LEE 1969). From the evidence we have obtained thus far, we infer that bacteria are required in the diet of foraminiferans for sustained reproduction (MULLER \& LEE 1969). They supply some nutritional factor required by foraminifera that is either unavailable or unavailable in sufficient quantity in an exclusively algal diet. With the exception of one species of Allogromia (LEE \& PIERCE 1963) low numbers of bacteria $(\sim 20,000 / \mathrm{ml})$ seem optimal for the foraminiferans we have tested.

The cultures of new organisms are incubated in an illuminated environmental chamber or a light bank at $25^{\circ} \mathrm{C}$ for one week. The mortality rate is high for new organisms harvested from field collections. In perhaps one out of 25 bowls the foraminiferans will reproduce within the first few weeks. The organisms are subcultured when the initial cultures reach densiries of 500 or more adults. Established cultures should be transferred about once a month for highest yield. Some species will grow and reproduce much longer; Allogromia laticollaris cultures, for instance, have been successfully maintained for over a year. without changing the media. The physiological conditions for optimum growth of a species must be studied experimentally. For example, the salinity range for each of 6 species isolated from the epiphytic community in North Sea Harbor varied greatly (MULLER \& LEE 1969), although the physical conditions at the times of collection seemed fairly comparable (LEE et al. 1969b). In culture the salinity range for A. laticollaris was 10-40\% $/ 00$; for Rosalina leei 25 to $35 \%$; for Spiroloculina byalina 30-40\%; for Quinqueloculina lata 45-55\%

Synxenic cultures of foraminifera have been recently isolated (MULIER \& LEE 1969) by the methods described above. After separating the foraminiferans from cultural associates by washing and picking with glass needles they were washed aseptically in 9-hole spot plates. The survivors were inoculated into various antibiotic mixes overnight and then transferred to cultures with axenic algae. In this manner gnotobiotic clones of Quinqueloculina lata, Spiroloculina byalina, Rosalina leei, and Allogromia laticollaris were established on bacteria + algae (usually 1 or 2 species). In these cultures $\mathrm{pH}$ became the limiting factor as the cultures aged. When waste products were removed by washing, reproductive rates were higher.

\section{Culture of nematodes}

Nematodes are collected and cultured using methods similar to those for foraminifera and algae. Positive aseptic field samples are inoculated into the series of liquid 
and solid differential media. Positive cultures are then subcultured in tissue culture flasks, petri dishes or on agar slopes of the same media. Otten the physical characteristics of the media seem important. For Rhabditis marina we found that the agar slopes had to be practically parallel to the walls of the test tubes. In deeper slopes the organisms buried themselves deeply in the agar and perished. Their bodies were found by the tracks of bacterial colonies which grew in their tunnels. Survival in liquid media is poor. We now grow most of our stocks in Pyrex screw-cap test tubes $(20 \times$ $125 \mathrm{~mm}$ ) with a long slope and $2-5 \mathrm{ml}$ of liquid overlay of the same medium. The tubes are incubated horizontally in test tube racks turned over on their sides. Chromadora sp. is also cultured on shallow slopes but grows best without any liquid overlay.

Synxenic cultures of 2 species, Rhabditis marina and Chromadora sp. have been established with the aid of washing techniques and antibiotics. A trixenic culture of $R$. marina (with 3 species of bacteria: Micrococcus sp., Pseudomonas sp., Flavobacterium marinum was fairly easily isolated. Three media, marine nutrient agar, \# 9 , and \# 10, supported good growth of the agnotobiotic stocks. Worms were harvested from stock cultures, gently washed aseptically in tubes of fresh liquid media with the aid of a vortex mixer, and inoculated into the three media containing either Novobiocin $100 \mu \mathrm{g} / \mathrm{ml}$, Colymycin $100 \mu \mathrm{g} / \mathrm{ml}$, or Erythromycin $50 \mu \mathrm{g} / \mathrm{ml}$. Neither Novobiocin nor Colymycin killed all the bacteria but both killed Rhabditis marina at the concentration employed. In several tubes treated with Erythromycin the nematodes reproduced well and no colonies of bacteria were observed on sterility tests. Transfers from these successful tubes into media with and without Erythromycin showed that bacteriostasis had occurred. A fungal mycelium grew on all the sterility tests. Both Mycostatin $(50 \mathrm{mg}-50 \mu \mathrm{g} / \mathrm{ml})$ and Fungizone $(5 \mathrm{mg}-50 \mu \mathrm{g} / \mathrm{ml})$ were tested against the fungus. The nematodes survived and reproduced in media $\# 7$ and $\# 9$ and marine nutrient agar treated with either antibiotic. After 4 serial transfers through Fungizonecontaining media fungal mycelia were no longer recovered from sterility tests.

Sensitivity tests showed that Erythromycin, Novobiocin, Polymyxin B, Chloramphenicol, and triple sulfa would eliminate one or more of the 3 bacteria in the culture. We tried these antibiotics at various concentrations singly and in combination in various media: 2, 7, 10, marine nutrient agar, and variations of these media with extra crude materials such as peptones and yeast extract. The initial and successive attempts were uniformly unsuccessful; either the nematodes perished or the bacteria were not eliminated. Attempts to isolate monoxenic cultures were successful. A tracer feeding experiment indicated that 2 of the 3 species of bacteria in the culture, Pseudomonas sp. and Flavobacterium marinum, were eaten by $R$. marina in large numbers. With the aid of Novobiocin $100 \mu \mathrm{g} / \mathrm{ml}$ and Erythromycin $50 \mu \mathrm{g} / \mathrm{ml}$ the worms were isolated in monoxenic culture with the Flavobacterium marinum. This culture was serially transferred 4 times and eventually failed on the 5th serial transfer. Eventual failure of the monoxenic culture could probably have been predicted, because generation time for the nematodes was greatly lengthened during successive transfers.

A monoxenic culture with the Pseudomonas sp. as food was successful and has been maintained for more than 80 generations. The monoxenic culture was established with the aid of $200 \mu \mathrm{g} / \mathrm{ml}$ Erythromycin. This concentration does not seem to harm 
the worms, is bacteriocidal for Flavobacterium marinum and Micrococcus sp. and bacteriostatic for Pseudomonas sp.

Axenic cultures have been established by aseptic washing and with the aid of 200-333 $\mu \mathrm{g} / \mathrm{ml}$ Erythromycin, and have been serially transferred 2 or 3 times in marine nutrient agar and medium $10+$ Bacto Peptone $0.05 \%$. Although we have tried various crude materials including BBL Trypticase, casein hydrolysate, serum fractions, yeast extract, Bacto Peptone, Mycological Peptone, sonicated bacteria, and metabolites such as amino acid mixtures, vitamin mixtures, etc. as bacterial substitutes, as yet we have not replaced living bacteria. Additional experiments are in progress.

Table 6

Marine nematodes in continuous culture

\begin{tabular}{|c|c|c|}
\hline Organism & Medium $(a)^{*}$ & Extent of development \\
\hline $\begin{array}{l}\text { Rbabditis } \\
\text { marina }\end{array}$ & $\begin{array}{l}\text { Marine nutrient } \\
\quad \text { agar } \\
9 \\
10\end{array}$ & $\begin{array}{l}\text { Monoxenic with Pseudomonas sp. in continuous } \\
\text { culture for } 16 \text { months ( } 80 \text { generations) }\end{array}$ \\
\hline Chromadora sp. & $\begin{array}{l}\text { Erdschreiber } \\
\quad 3\end{array}$ & $\begin{array}{l}\text { Synxenic with B1 } 38, \mathrm{~B} 127 \text {, and } 38 \text { plus several } \\
\text { species of bacteria; in continuous culture } 12 \\
\text { months ( } 24 \text { generations) }\end{array}$ \\
\hline Chromadora axi & $\begin{array}{l}\text { Erdschreiber } \\
\quad 3\end{array}$ & $\begin{array}{l}\text { Aseptically transferred with } \mathrm{Bl} 38 \text { and unknown } \\
\text { bacteria; in continuous culture } 4 \text { months (8 ge- } \\
\text { nerations) }\end{array}$ \\
\hline $\begin{array}{l}\text { Chromadora } \\
\text { quadrilinea }\end{array}$ & $\begin{array}{l}\text { Erdschreiber } \\
\quad 3\end{array}$ & $\begin{array}{l}\text { Aseptically transferred with } \mathrm{Bl} 38, \mathrm{BL} 52 \text { and } \\
\text { unknown bacteria; in continuous culture } 4 \text { months } \\
\text { ( } 8 \text { generations) }\end{array}$ \\
\hline $\begin{array}{l}\text { Oncholaimus } \\
\text { paralangruensis }\end{array}$ & $\begin{array}{l}\text { Erdschreiber } \\
\quad 3\end{array}$ & $\begin{array}{l}\text { Aseptically transferred with Bl } 38+\text { unknown } \\
\text { bacteria; in continuous culture } 4 \text { months; } 2-3 \\
\text { generations }\end{array}$ \\
\hline $\begin{array}{l}\text { Viscosia } \\
\text { carnleyensis }\end{array}$ & Liquid sea water & Agnotobiotic; in continuous culture 25 months \\
\hline \multicolumn{3}{|c|}{$\begin{array}{l}\text { * See Table } 1 . \\
\text { * For identification see MulLER \& LEe (1969). }\end{array}$} \\
\hline
\end{tabular}

We have just begun to direct our attention to the other species of nematodes we have in culture. The species of Chromadora were isolated from initial agnotobiotic cultures into media containing algae from our stocks or isolated axenically from previous field collections of the same organism. Food quality seem important to the various species of nematodes since cultures were successful with some species of algae and not with others. Our results to date are summarized in Table 6.

\section{DISCUSSION}

One needs only look to the studies of FøYN (1934), Provasoli et al. (1957) and Provasoli (1963) to appreciate the slow rate of progress in the development of marine media. Although technological progress in the form of air conditioning, environmental chambers, practical refrigerated marine aquaria, new culture devices (ARNold 
1966, 1967), etc. has increased our ability to continuously culture more organisms in the laboratory, the old nutritional problems still remain. The nutritional requirements of the multicellular algae and herbivores in culture are probably much more complex than those of many unicellular algae. As Provasoli (1963) has stated, "Nutrition and morphogenesis in multicellular algae strains our ingenuity". His point has broader implications. One can only hope that the growth of the field will provide more workers for the slow, painstaking aspects of gnotobiotic nutrition.

On the other hand, new techniques like tracer feeding have broken the bottlenedk of synxenic culture for a wide variety of small invertebrate herbivores by greatly shortening the time required to test potential food. For example, questions on foraminiferan nutrition which used to take months to answer can be answered in days (LeE et al. 1966). It took us over 10 years to isolate 5 species of foraminifera in synxenic culture, and yet, perhaps because we have improved media and a larger variety of potential food organisms in culture, in a little more than a year 5 species of nematodes were brought into culture. As we gain more knowledge on the nutrition of the unicellular algae in the epiphytic community and evolve new media, we hope to isolate as yet "untamed" organisms in synxenic culture.

Although axenic cultures are desirable for most studies, useful physiological and life cycle information can be gained from organisms in synxenic culture. Perhaps some day one of our present goals will be achieved, and the subtle variables which regulate the structure of even $1 \mathrm{~mm}^{2}$ of a salt marsh epiphytic community will be within our grasp.

\section{SUMMARY}

1. Members of the epiphytic communities of Zostera, Enteromorpha, Ulva and other marine macrophytes occurring in North Sea Harbor, Southampton, New York are being isolated in gnotobiotic culture as part of a broader program of studies on the trophic dynamics and mineral cycling of the community.

2. Aseptic samples are taken in the field, by means of sterile forceps, and inoculated into $30 \mathrm{ml}$ of sterile sea water from the same station. The samples are refrigerated and brought as soon as possible to a nearby field laboratory where they are inoculated into a series of (26) differential media. These media (LEE et al. 1966), originally based on the formulation of PINTNER \& Provasoli (1957), have been modified each year as more experience with the nutrition of the isolates from the community is gained. Incubation is usually $1-3$ weeks at $15-25^{\circ} \mathrm{C}$. Many diatoms, chlorophytes, bacteria, and yeasts can be isolated axenically from clones grown on solidified initial isolation media.

3. Other organisms are isolated from agnotobiotic media by: (a) streaking onto solidified media; (b) aseptic washing of individual organisms in 9-hole spot plates; (c) inoculation into antibiotic-containing media; and (d) combination of several or all of the above techniques. Much of the isolation and transfer is performed under a stereoscopic microscope enclosed in a Germ Free microscope glove-box. Tracer feeding techniques are used to identify food for gnotobiotic culture of herbivores (LeE et al. 1966). 
4. Among the goals of our studies are: (a) the characterization of the microbial community structure of epiphytic communities in comparable unpolluted and polluted areas and study changes in time and space; (b) isolation of the key members of the microbial community in axenic culture and study of their physiological ecology as well as responses to stress conditions; (c) using the above cultures, to construct meaningful small defined microcosms and through experimental manipulations to define the subtle variables which regulate community structure.

5. To this end we now have in continuous gnotobiotic culture Enteromorpha intestinalis, Ulva lactuca, approximately 70 species of salt marsh diatoms, chrysophytes, dinoflagellates and chlorophytes, six species of foraminifera, and three species of nematodes. In agnotobiotic culture are additional species of harpactacoid copepods, ostracods, amphipods, flagellates, and ciliates associated with epiphytic communities.

\section{LITERATURE CITED}

ARNold, Z. M., 1966. A laboratory system for maintaining small volume cultures of foraminifera and other organisms. Micropaleontology 12, 109-118.

- 1967. Utilization des antibiotiques dans la réalisation des cultures de foraminifères sous faible volume. II. Application à la technique des cultures des foraminifères. Vie Milien (Sér. A) 18, 36-45.

Føyn, B., 1934. Lebenszyklus und Sexualität der Chlorophycee Ulva lactuca. Arch. Protistenk. 83, 154-177.

Freudenthal, H. D. \& Lee, J. J., 1963. Glenodinium balli and Gyrodinium instriatum n. sp., Dinoflagellates from New York waters. J. Protozool. 10, 182-189.

- - \& Pierce, S., 1963. Growth and physiology of foraminifera in the laboratory. Pt 2. Collection and maintenance: a tidal system for laboratory studies on eulittoral foraminifera. Micropaleontology 9, 442-448.

Hutner, S. H., Cury, A. \& Baker, H., 1958. Microbiological assays. Analyt. Chem. 30, 849-867.

Lee, J. J., Freudenthal, H. D., Muller, W. A., Kossoy, V., Pierce, S. \& Grossman, R., 1963. Growth and physiology of foraminifera in the laboratory. Pt 3. Initial studies of Rosalina floridana Cushman. Micropaleontology 9, 449-466.

- McEnery, M., Pierce, S., Freudenthal, H. D., Muller, W. A., 1966. Tracer experiments in feeding littoral foraminifera. J. Protozool. 13, 659-670.

- - \& RubnN, H., 1969a. Quantitative studies on the growth of Allogromia laticollaris (foraminifera). J. Protozool. 16, 377-395.

- Muller, W. A., Stone, R. J., McEnery, M. \& Zucker, W., 1969b. Standing crop of foraminifera in sublittoral epiphytic communities of a Long Island salt marsh. Mar. Biol. $4,44-61$.

- \& Pierce, S., 1963. Growth and physiology of foraminifera in the laboratory. Pt 4. Monoxenic culture of an allogromiid with notes on its morphology. J. Protozool. 10, 404-411.

- \& Zucker, W., 1969. Algal flagellate symbiosis in the foraminifer Archais. J. Protozool. 16, 71-81.

Lindeman, R. L., 1942. The trophic-dynamic aspect of ecology. Ecology 23, 399-418.

LотKA, A. J., 1956. Elements of mathematical biology. Dover Press, New York, 465 pp.

McArthur, R. A., 1960. On the relative abundance of species. Am. Nat. 94, 25-36.

McEnery, M. \& LeE, J. J., 1969. Tracer studies on mineralization and mineral cycling in Rosalina leei and Spiroloculina byalina. Limnol. Oceanog. (in press).

McLaughlin, J. J. A. \& ZAHL, P., 1959. Axenic zooxanthellae from various invertebrate hosts. Ann. N.Y. Acad. Sci. 77, 55-72. 
Mullek, W. A. \& LeE, J. J., 1969. Apparent indispensability of bacteria in foraminiferan nutrition. J. Protozool. 16, 471-478.

PATTEN, B. C., 1962. Species diversity of net phytoplankton of Raritan Bay. J. mar. Sci. 20, $57-75$.

- 1966. The biocoenetic process in an estuarine phytoplankton community. National Laboratory, Oak Ridge, Tenn. (Rep. No ORNWL 3946 - U C - 48 - Biology and Medicine.)

Pintner, I. \& Provasoli, L., 1958. Artificial cultivation of a red-pigmented marine blue-green alga, Phormidium persicinum. J. gen. Microbiol. 18, 190-197.

Provasoli, L., 1963. Growing marine seaweeds. Int. Seaweed Symp. 4 (Biarritz), 9-17.

- McLaughits, J. J. A. \& Droop, M. R., 1957. The development of artificial media for marine algae. Arch. Mikrobiol. 25, 392-428.

VolterRA, V., 1931. Leçons sur la théorie mathématique de la lutte pour la vie. GauthierVillars, Paris.

Watkrns, J. G., 1961. Foraminiferal ecology and the Orange County, California, Ocean sewer outfall. Micropaleontology 7, 199-206.

First author's address: Dr. J. J. LeE

Department of Biology

City College of New York

New York 10031, USA 